\title{
ВЗАИМОСВЯЗЬ МЕЖДУ МЕЖДУНАРОДНЫМ ПУБЛИЧНЫМ И НЕФТЯНЫМ ПРАВОМ: ИЗУЧЕНИЕ ДЕЛА МЕЖДУ ТИМОРОМ- ЛЕШТИ И АВСТРАЛИЕЙ
}

\section{ОРИГИНАЛ СТАТЬИ}

PEREIRA, Jeremias ${ }^{1}$

PITHAN, Lívia Haygert ${ }^{2}$

PEREIRA, Jeremias. PITHAN, Lívia Haygert. Взаимосвязь между международным публичным и нефтяным правом: изучение дела между Тимором-Лешти и Австралией. Междисциплинарный научный журнал Core знаний. 04 год, Эд. 12, Vol. 02, стр. 31-51. Декабрь 2019 года. ISSN: 2448-0959, ссылка

для

доступа: https://www.nucleodoconhecimento.com.br/закон/международно-

публичное-право

\section{PE3ЮME}

Эта статья направлена на анализ морского права и нефти, с тем чтобы понять причины, порождающие на протяжении более десяти лет конфликт между Тимором-Лешти и Австралией в отношении определения окончательных морских границ. Тимор-Лешти уже эксплуатируется и вторгается в него несколькими странами. Из-за обилия нефти и природного газа, он пострадал, чтобы обрести независимость в 2002 году, а также изо всех сил пытался пользоваться своей морской территории до 2018 года, из этого нового контекста

1 Академическая юридическая школа, юридический фракультет, Папский католический университет Рио-Гранде-ду-Сул - PUC-RS.

2 Консультантом. Кандидат наук в области частного права. Степень магистра права. Степень ютегов.

RC: 45098

Disponível em: https://www.nucleodoconhecimento.com.br/закон/международно-публичное- 
договора о морской границе, подписанного между Тимором-Лешти и Австралия. Средняя линия равновесия является параметром, используемым для определения окончательных тиморских границ, что дает право пользоваться своей морской территорией. Окончательный пакт о границах в значительной степени способствовал развитию Тимора-Лешти в связи с эксплуатацией морских богатств, а также признал необходимость оказания помощи нефтяным компаниям в развитии Тимора-Лешти конкретным и пунктуальным образом. Теперь это должно быть ратифицировано национальными парламентами обеих стран. Процесс ратификации должен быть завершен в 2019 году. В настоящее время Тимор-Лешти пытается провести переговоры со своими морскими границами с Индонезией, однако они были приостановлены в ходе обязательного согласительного процесса с Австралией. Теперь, когда этот процесс закончен, обе страны могут возобновить свои дискуссии.

Ключевые слова: Нефтяное право, международное право, морское право.

\section{1. ВВЕДЕНИЕ}

На протяжении более десяти лет Австралия и Тимор-Лешти не согласны с морскими границами каждого из этих государств. Спор возникает из-за права на разведку нефти и других морских богатств и препятствий на пути экономического и политического развития Тимора-Лешти после подписания договора с Австралией. Таким образом, данная статья развивается в области публичного международного права, в частности в области нефтяного права.

Возникает вопрос о том, сбалансирован ли договор между Австралией и Тимором-Лешти об определении морских границ, полностью сохраняя право тиморцев. Каковы препятствия, препятствуя недопуску этой нации к непропорциональной эксплуатации со стороны других стран и могут развиваться с 2019 года?

Актуальность этого исследования оправдана тем фрактом, что необходимость австралии уважать морские границы Тимор-Лешти оправдана. В XXI веке, RC: 45098

Disponível em: https://www.nucleodoconhecimento.com.br/закон/международно-публичное- 
несмотря на существование международного права и нефтяного права, Австралия не была заинтересована в осуществлении Договора, в котором права Тимор-леста были признаны морской территории. Историческая экономическая хрупкость страны с гораздо меньшим земельным пространством, чем моряк, сделала ее объектом эксплуатации таких стран, как Индонезия и Австралия. Несмотря на то, что в 2018 году между Тимором-Лешти и Австралией был подписан постоянный договор, необходимо изучить несколько правовых документов, касающихся морского и нефтяного права, с целью умножения инструменты защиты от других государств, которые намерены неоправданно использовать территориальное пространство Тимора-Лешти в связи с нынешней экономической неустойчивостью. ${ }^{[3]}$

Тимор-Лешти до 1975 года принадлежал Португалии, ее поселенцам. С 1976 года Индонезия вторглась в него и начала эксплуатировать его, и только с помощью Организации Объединенных Наций (OОH) эта страна избрала своего первого президента республики в 2001 году, став независимым государством и членом ООН в 2002 году. Несмотря на независимость, Тимор-Лешти страдает от тирании Австралии, не получив фринансовых ресурсов для эксплуатации своей морской территории. Португалия, Индонезия и Австралия никогда не инвестировали должным образом в Тимор-Лешти, хотя они собрали миллионы от добычи нефти в этом регионе, а также других богатств. Из-за десятилетий низких фринансовых инвестиций тиморскому народу необходимо развиваться очень политически и юридически, с тем чтобы оно происходило в условиях экономического развития. ${ }^{[4]}$

Общая цель этой научной работы заключается в анализе международного и нефтяного права для понимания причин, порожденных более десяти лет назад конфрликтом между Тимором-Лешти и Австралией на морских границах. Для понимания проблемы, связанной с морской территорией Тимор-Лешти, было намечено несколько конкретных целей, таких, как 
а) представить обзор, политическое, историческое, правовое и экономическое видение Тимора-Лешти и его отношений с Австралией;

б) изучить международное право, касающееся моря;

в) использовать право на нефть;

d) проанализировать договор о границах между Тимором-Лешти и Австралией.

Эта статья разделила на четыре части: возможности политико-социальной, исторической, правовой и экономической эволюции Тимора-Лешти будут проанализированы на протяжении всего исследования для достижения, анализа и проверки того, является ли Договор между Австралия и Тимор-Лешти фактически будут способствовать развитию тиморского общества. Исходя из этой информации, необходимо будет понять причины, покоторым которые привели народ Тимора-Лешти к низкому уровню развития в ряде областей.

Первая глава посвящена историческим и географическим аспектам, помимо эксплуатации Тимора-Лешти другими странами, в историческом контексте, с тем чтобы понять причины нынешнего правового, экономического, политического и социального контекста этой страны.

Во второй главе рассматриваются аспекты на границах Тиморского моря и важности международных отношений для этой страны. Этот анализ имеет функцию наблюдения за фракторами, благоприятствующим тому, чтобы тиморский народ вновь стал жертвой со стороны исследователей из-за их экономической нестабильности сегодня. Чтобы понять механизмы защиты государства в связи с морскими нападениями, необходимо учитывать международное морское право. Эта часть международного права касается согласованных на международном уровне стандартов и принципов, связанных с собственностью, использованием, эксплуатацией и защитой моря и его ресурсов во всем мире. ${ }^{[5]}$ 
В третьей главе будут изучены концепции и значение нефти и ее значение для развития государств, которые имеют огромное морское территориальное пространство и небольшое сухопутное пространство, такое, как Тимор-Лешти.

Нефть была обнаружена в 19 веке и, с момента ее создания, были важные преобразования в человечество, Это однородная смесь органических соединений, в основном углеводородов, нерастворимых в воде. Этот источник питания также известен как сырой. С 1859 года он считается драгоценностью и в 21 веке он яростно жаждет соответствующей роли, которую он играет в современном мире. Безудержные поиски Австралии и Индонезии в целях энергоснабжения и экономического развития привели к ряду конфликтов с Тимором-Лешти из-за стремления некоторых стран эксплуатировать не принадлежащие им морские территории. Чрезвычайно важно понять, каким образом происходит добыча нефти, а также такие ресурсы, как природный газ, чтобы понять причины, которые привели к неоправданной эксплуатации в течение десятилетий тиморской нефти. [6]

Впоследствии препятствия на пути развития Тимора-Лешти присутствуют в четвертой главе. Отношения с международным сообществом чрезвычайно актуальны для развития этой страны. Достижения в правовой и политической сорере имеют важное значение для экономической эволюции. Компании, ответственные за эксплуатацию природных ресурсов морской территории, должны вести переговоры с подготовленными и подготовленными тиморскими специалистами, с тем чтобы эти соглашения предоставляли Тимору-Лешти много преимуществ. ${ }^{[7]}$

Настоящее исследование направлено не на исчерпание всех вопросов, а скорее на стимулирование дискуссий о конфликте между Тимором-Лешти и Австралией. Методика исследования, используемая в этой работе, будет состоять из библиографических исследований, путем анализа доктрин, научных статей, виртуальных библиотек, а также исследований в правовых текстах с веб-сайтов, признанных информационными средствами аккредитован правительством 
Тимора-Лешти. Принятый метод будет индуктивным процессом, с помощью которого студент, изучая несколько позиций индоктринаторов, начнет с нескольких конкретных понимания определенных авторов, чтобы прийти к нескольким общим выводам. В связи с этим вопросом будет проведено библиографическое исследование, в частности, с каждым подглавой резюме для достижения общего вывода по проблеме. ${ }^{[8]}$

\section{2. ТИМОР-ЛЕШТИ, ГЕОГРАФИЯ, ИСТОРИЯ, ЭКОНОМИКА И ПОЛИТИКА}

Демократическая Республика Тимор-Лешти является прибрежной страной. Его основные экономические продукты ямс, кукуруза, кофе, дым, каучук, белый сандаловое дерево, крупный рогатый скот, свиньи, буйволы, среди других. Эта страна расположена на острове Тимор и граничит с Индонезией и Австралией. Его территория соответствует участкам этого острова, потому что в 1975 году, во времена независимости Португалии, другая половина архипелага больше не принадлежала португальскому достоянию. Из-за этой ситуации, в настоящее время есть часть острова, который является территорией Индонезии. Он расположен в юго-восточной Азии, на южной окраине индонезийского архипелага, к северо-западу от Австралии, недалеко от Океании. К югу, это от 250 до 400 морских миль через Тиморское море с материковой части Австралии.

Морская территория этой страны, которая имеет обилие нефти и природного газа, всегда привлекала жадность различных стран. Договоры и вторжения, которые наносили ущерб тиморцам в различные исторические периоды, проявляются в стремлении вторгнуться и вступить в должность, с тем чтобы стать законной властью для осуществления эксплуатации Тиморского моря. Для того чтобы получить преимущество, Австралия была единственной страной в мире, которая официально признала незаконную аннексию Тимора-Лешти Индонезией в 70-х годах, хотя есть резолюция Совета Безопасности Ассамблеи Организации Объединенных Наций Объединенные Нации, которые осудили это вторжение. ${ }^{[9]}$

Disponível em: https://www.nucleodoconhecimento.com.br/закон/международно-публичное- 
Правообладатель иллюстрации Getty Images Image caption Морские границы Тимора-Лешти

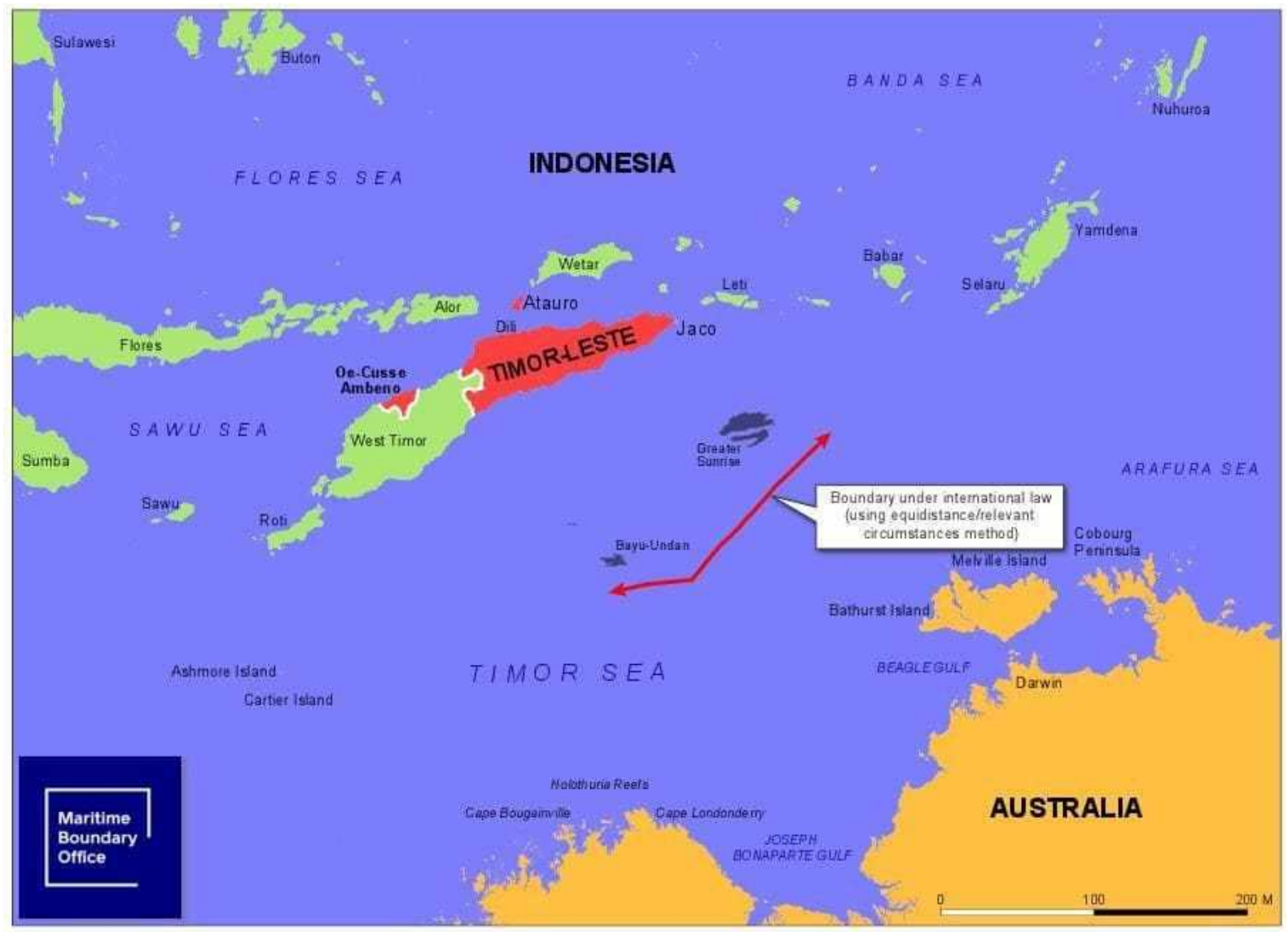

Источник: Морское пограничное управлени[10]

е (2018)Тимор-Лешти уже исследовалось Португалией, Японией, Индонезией и Австралией в разные периоды. Исторический контекст этой республики является фактором, который раскрывает причины нынешнего социального, политического и экономического положения этой страны. Эта страна, которая имеет небольшую территорию земли и около одного миллиона жителей, необходимо развивать много в нескольких областях, потому что это молодая страна. Португалия была доминантой Тимора-Лешти с 1515 по 1975 год и мало инвестировала в ее рост. С 1942 по 1945 год, во время Второй мировой войны, он был оккупирован Японией, но вскоре португальцы восстановили власть этой колонии. В апреле 1975 года в Португалии появилось политическое движение вооруженных сил,

Disponível em: https://www.nucleodoconhecimento.com.br/закон/международно-публичное- 
известное в народе как 3D, с целью деколонизации, демократизации и развития. В этот период в Тиморе-Лешти родилось революционное движение, известное как ФРЕТИЛИН, Революционный фронт независимого Тимора-Лешти. 28 ноября 1975 года произошла его независимость, движимая Движением тиморезов. Независимость наблюдалась только в течение десяти дней. ${ }^{[11]}$

Индонезия в июле 1975 года вторглась в Тимор-Лешти, оставаясь на этой территории примерно в течение двадцати шести лет, в то время, когда произошло много случаев смерти от болезней и нехватки продовольствия. Международное сообщество было тронуто геноцидом, который там произошел. В 1999 году ООН вместе с Португалией заключила соглашение с Индонезией, которое касалось возможности проведения референдума. В августе 1999 года тиморцы большинством голосов проголосовали за независимость, поскольку 78\% населения больше не согласны с резней, которой они подверглись. Но доминатора не приняли освобождение. Индонезийские военнослужащие пытали и убивали людей. Многие тиморцы бежали в западную часть острова, в то время как все, что было построено вдоль вторжения, было уничтожено в этой стране. Для того чтобы контролировать резню, ООН приняла резолюцию 1246 августа 1999 года о создании многонациональных сил для стабилизации ситуации. После ухода из Индонезии Тимор-Лешти стал получателем помощи от международного сообщества, поскольку были человеческие жертвы и неисчислимые материалы. 20 мая 2002 года при неоказании помощи была восстановлена независимость Демократической Республики Тимор-Лешти, что было признано первым демократически избранным правительством. [12]

Интерес Австралии к Тимору-Лешти не является чем-то новым. Австралийцы имели информацию о том, что в Тиморском море много газа и нефти. С момента открытия в 1960 году, что в Тиморском море имеется богатство, иностранные правительства пытались доминировать на острове. В 70-х годах Австралия была единственной страной, которая признала, что западная половина острова Тимор принадлежит Индонезии. Оказывается, что в 1970 году австралийская компания

Disponível em: https://www.nucleodoconhecimento.com.br/закон/международно-публичное- 
Woodside Petroleum обнаружила огромный запас газа в регионе, известном как Санрайз и Трубадур-Филдс или Большой Восход. ${ }^{[13]}$ Намерение вести переговоры о территориальных преимуществах является одной из причин, по которым австралийцы игнорируют негативное мнение международного сообщества, которое не согласно с поведением Индонезии вторгнуться в западную часть острова Тимор. Заинтересованность в получении прибыли от открытия богатства в Тиморском море, Индонезия и Австралия подписали договор. Этот документ касался морских границ между двумя странами, однако Австралия захватила территорию, на которой находились запасы газа. Недовольные подписанным в 1975 году Договором Индонезия вторглась в Австралию, чтобы получить процент от эксплуатации газовых ресурсов в этом регионе. Тиморцы не согласны с договором, который разделяет богатство их территории между Индонезией и Австралией, однако два иностранных государства, участвующие в международном соглашении, игнорируют позицию мира, вопреки их пакту. 20 мая 2002 года, в день восстановления независимости Тимор-Леште, страна стремилась овладеть территорией, которая на нее имеет право. Тимор больше не принадлежит Индонезии. Договоры, которые были согласованы до обретения независимости, более не являются ценными. ${ }^{[14]}$

В 2002 году Австралия с целью сохранения доминирующей морской территории, которая будет принадлежать Тимору-Лешти, отказалась от всех обязательных пограничных процедур, частью которых она является. В 2006 году между Австралией и Тимором-Лешти был заключен Договор о некоторых морских корректировках в Тиморском море, который не понравился тиморцам, поскольку он служит для того, чтобы избежать изменений в правовых переговорах или судебных исках в течение пятидесяти лет. Именно в 2016 году люди, которые почувствовали ущерб от Договора, уведомили австралийцев о том, что он решит проблему морских границ путем обязательного примирения, предусмотренного Конвенцией ООН, статьей 298 и приложением V, в котором Права на море. ${ }^{[15]}$

Доминирование Тимора-Лешти другими государствами в различные исторические периоды нанесло ему значительный ущерб. В развитии тиморского

Disponível em: https://www.nucleodoconhecimento.com.br/закон/международно-публичное- 
народа в различных областях ощущается ряд отражений эксплуатации Индонезии и Австралии. С 2002 года, накануне независимости Тимора-Лешти, австралийцы вышли из ряда международных договоров, с тем чтобы предотвратить потерю эксплуатации неморской территории. Австралийцы и тиморцы имеют отдельные территории на расстояние менее 400 морских миль. Из-за близости между двумя странами их морские территории должны определяться своеобразно и конкретно, в соответствии с принципом справедливости. Необходимо углубить знания о морском праве и нефти, с тем чтобы понять причины фракта и права, которые узаконивают борьбу тиморского народа за свою морскую территорию. [16]

\section{3. СПРАВА ОТ МОРЯ И НЕФТИ}

Морское право относится к международному праву, которое соблюдает суверенитет и юрисдикцию государств, определяя масштабы их морской сферы. Он также регулирует ряд других вопросов, таких, как эксплуатация существующих ресурсов на дне и на морском дне, в дополнение к сохранению и сохранению морской среды. ${ }^{[17]}$ Одним из величайших богатств, обнаруженных на дне Тиморского моря, является нефть, которая выделяется как вязкая, легковоспламеняющаяся черная жидкость, менее плотная, чем вода. Он состоит из смеси углеводородов, молекул, состоящих из атомов углерода и водорода, а также молекул серы, азота, кислорода и ионов металла, и находится в естественных подземных резервуарах. ${ }^{[18]}$

Конференция по морским правам состоялась в 1958 году. В 1969 году он был ратифицирован почти всеми странами мира. В нем рассматриваются различные темы или темы, которые касаются тесной связи в океанском пространстве между государствами. Конвенция Организации Объединенных Наций о правах моря 1982 года была подписана в Монтего-Бей, Ямайка, хотя она и была опубликована на женевской конференции. В этом документе есть правила и принципы территориального моря, смежных, эконо ${ }^{[19]}$ мических и континентальных районов. ${ }^{[20]}$ Что касается суверенитета прибрежного государства над

Disponível em: https://www.nucleodoconhecimento.com.br/закон/международно-публичное- 
прилегающими водами, то оно ${ }^{[21]}$ регулирует все страны, которые приняли его, приняли или ратифицировали его. Существуют также соответствующие стандарты в области управления морскими ресурсами и борьбы с загрязнением. ${ }^{[22]}$

ПРООН определяет, что море побережья имеет 12 морских миль, то есть 22 км. На вертикальном самолете, он простирается до воздушного пространства, имея его в качестве предела. Морская вода поверхности ограничена при контакте с океанским дном, почвой, а также все недропользованием регулируется территориальным морским правовым режимом. ${ }^{[23]}$ Право моря на прибрежные государства было гарантировано исключительной экономической эксплуатацией в воздухе в 200 морских миль, однако это правило не распространяется на государства, которые находятся менее чем в 400 милях от их прилегающих районов. ${ }^{[24]}$

Рисунок 2 - Территориальное море

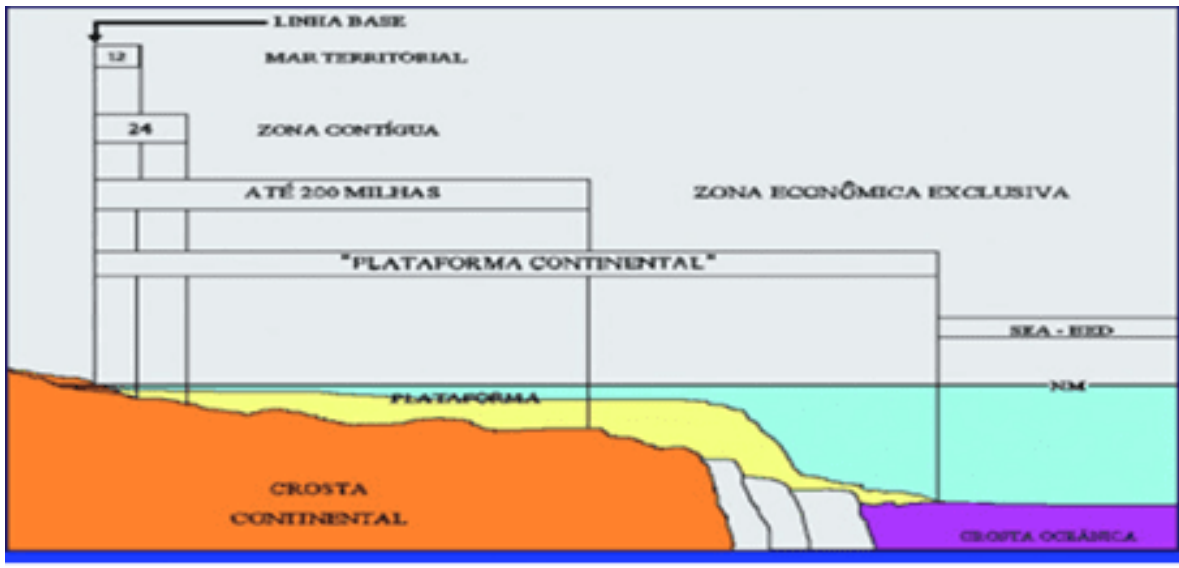

Источник: ГУСМЯО (2018).

Территориальное море - это район, расположенный между внутренними водами и в открытом море. Согласно статьям 2 и 3 КООНЛОС, она является продолжением суверенитета прибрежной страны, превышающей ее территорию и ее воды. ${ }^{[25]}$ Государство осуществляет суверенитет над своим территориальным морем, воздушным пространством, а также дном и недрами

Disponível em: https://www.nucleodoconhecimento.com.br/закон/международно-публичное- 
под территориальным морем, сообщает Ст. 02-32 Конвенции о правах моря. ${ }^{[26]}$ Внешняя граница территориального моря каждого народа составляет двадцать два километра. Государство осуществляет свою юрисдикцию в отношении деятельности, представляющей национальный интерес в прилегающей морской зоне, которая составляет 12 миль. Конвенция Организации Объединенных Наций создала исключительную экономическую зону ИЭ3, чтобы сбалансировать интересы между странами. Это район, расположенный за территориальным морем. Он относится к району вблизи прилегающей зоны и простирается до 200 миль от побережья. Государство имеет право ориентироваться, летать над недрами, устанавливать кабели и морские протоки, а также эксплуатировать полезные ископаемые, найденные в почве и морских недрах. Тимор-Лешти и Австралия разделены менее чем на 400 миль, и по этой причине это правило не разрешает конфликты на границах между двумя странами. ${ }^{[27]}$

Тиморцы и австралийцы являются народами, принадлежащими к государствам с прилегающими или расположенными между побережьем. Они не отвечают ограничениям, установленным Конвенцией Организации Объединенных Наций о применении прав моря, связанных с суверенитетом государства в территориальном море. Расстояние от прибрежного побережья между странами составляет 300 миль. Эти страны должны разграничить морские границы на уровне соглашения, определяемого нормами международного права. Государства должны достичь справедливого, справедливого и равноценного решения. ${ }^{[28]}$

В женевской конвенции имеются критерии параллельного делимитации. Метод медианной линии используется в особых обстоятельствах для состояний с противоположными спинами. Он регулирует корректировку средней линии между странами. В Конвенции по морскому праву говорится, что ввиду отсутствия расстояния в 400 миль для разделения двух стран следует использовать принцип равноправия. [29] 
Нефтяная промышленность чрезвычайно важна. Сегодняшнее общество зависит от него и его производных. Это ископаемое топливо, источник электрической энергии для большинства развитых и развивающихся стран. Это необходимо для производства целого ряда продуктов, таких как дизельное топливо, керосин и бензин. Он также присутствует в вводимых ресурсов и в нефтехимической промышленности, через парафин и нафрту. Многие лекарства имеют в своем составе нефтепродукты. Невозможно размышлять о текущих формах человеческой жизни без асфральта, пластики и аспирина. Масло можно наблюдать в топливе, используемом для передвижения людей. Он содержится во множестве химических веществ и нефтепродуктов, основополагающих для развития нации. Из-за своей обширной применимости и потому, что он является изнурительным источником энергии, австралийцы игнорировали международное морское право в течение многих лет. Они вышли из состава ПРООН, с тем чтобы не дать тиморскому народу получить прибыль от эксплуатации нефтяных компаний "Байу Ундан" и "Большой восход".[30]

В связи с важностью нефти, Организация стран-экспортеров нефти (ОПЕК) возникла в Вене, Австрия в 1960 году. Странами-основателями были Исламская Республика Иран, Ирак, Кувейт, Саудовская Аравия и Венесуэла. ЦельОрес заключается в выработке общей политики в отношении нефти, защищая доходы стран-производителей. До создания этой организации страны-экспортеры нефти, которые владели большей частью запасов нефти того времени, получали недоходные выгоды. Огромные корпорации регулировали международный нефтяной рынок. Стоимость ископаемого топлива, выплачиваемого странампроизводителям и перепродажи конечному потребителю, контролировалась нефтяными компаниями. Американские компании Exxon, Texaco, Amoco и Chevro, а также голландская Royal Dutch Shell и British Petroleum назывались Seven Sisters. Они занимались разведкой, переработкой, транспортировкой и перепродажей нефти, но лишь малая часть плодов добычи предназначалась для государств-производителей. В настоящее время Организация Объединенных Наций также следит за действиями нефтяных компаний, с тем чтобы можно было 
договориться между государствами-производителями и нефтедобывающими компаниями. ${ }^{[31]}$

Тимор-Лешти десятилетиями исследовался Австралией. Такое поведение было В значительной степени обусловлено экономическими причинами, обусловленными интересом к богатству тиморской морской территории. Не ново, что нефтяная промышленность мотивирована на то, чтобы исключить Австралию из международного сообщества. Австралийцы не желают заниматься вопросами, связанными с правами моря. Интерес к прибыли в связи с добычей нефти и природного газа из региона, принадлежащего Тимору-Лешти, не позволил достичь там соглашения между двумя странами на протяжении многих лет. ${ }^{[32]}$

С момента обретения независимости в 2002 году Австралия нанесла ущерб тиморцам. Все запасы нефти и газа находятся на тиморской стороне средней линии, т.е. ближе к Тимору-Лешти, чем к австралийской территории. Австралия больше не признает юрисдикцию Международного Суда и Конвенции Организации Объединенных Наций по морскому праву в отношении разграничения своих границ по средней линии с Тимором-Лешти за несколько месяцев до обретения независимости. Исключение Австралии из ПРООН было намерением избежать утраты или сокращения морского территориального пространства, поскольку оно принадлежит тиморцам. Конвенция Организации Объединенных Наций о правах моря гласит, что каждая страна должна деконсировать как исключительную экономическую зону в 200 морских милях от внешнего предела своего территориального моря, в 12 милях от побережья. ПРООН также занимается большими глубинами моря, которые известны как Площадь или Зона А, согласно искусству. 1. Этот район состоит из морского и океанского днаи и их недр. ${ }^{[33]}$ 
Рисунок 3 - Линия демаркации границы Австралии

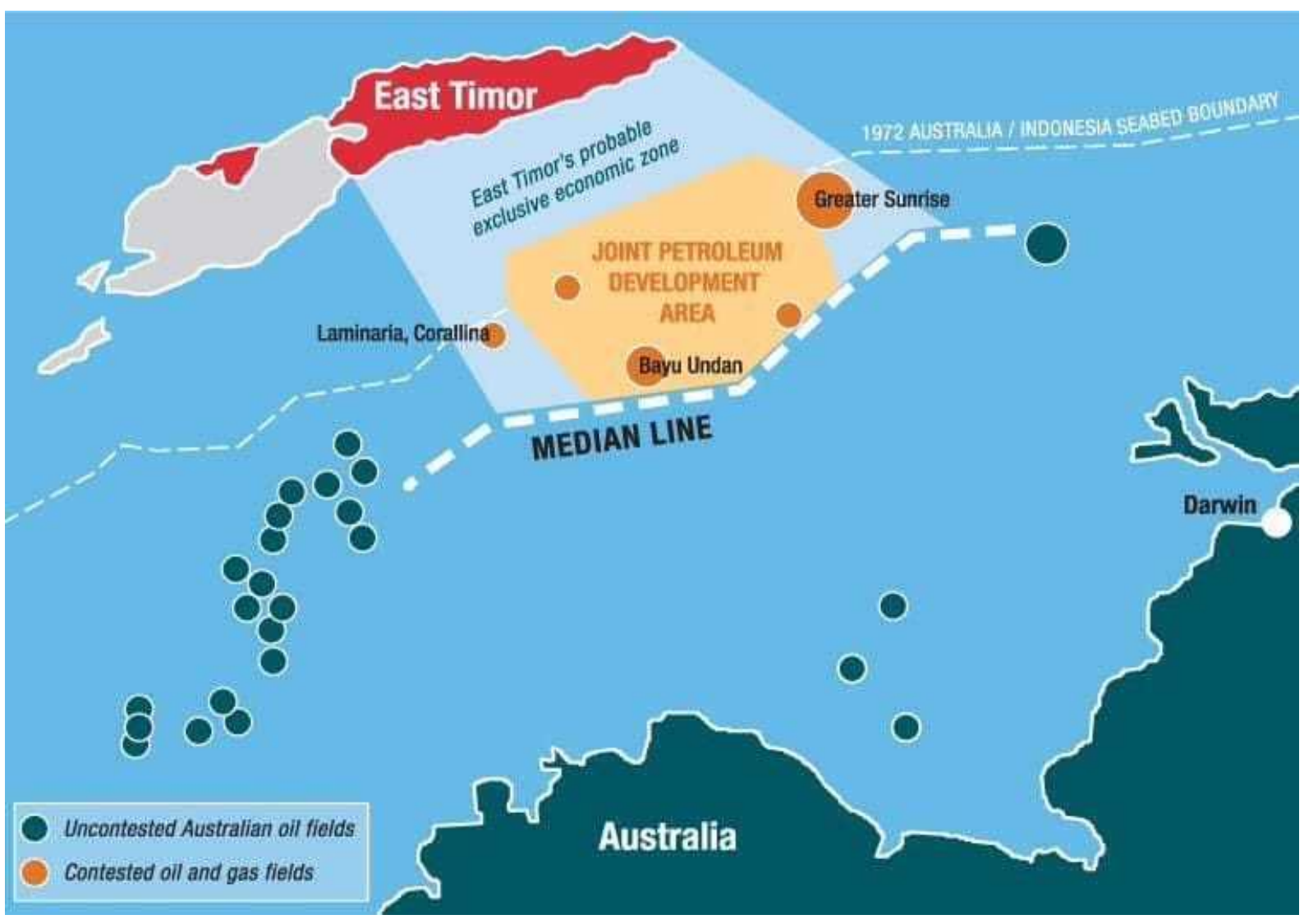

Источник: TIMOR SEA JUSTICE (2016). [34]

Принципы, содержащиеся в Конвенции Организации Объединенных Наций о правах на море, заявляют, что морская граница между двумя заинтересованными странами должна определяться равномерной линией, т.е. средней линией. Демаркация границ между Австралией и Тимором-Лешти по принципу равного расстояния включает в себя тиморскую территорию со всей разведочной зоной скважины нефтяной компании "Байу Ундан". Нефтяное месторождение Большой Восход расположено в так называемой зоне сотрудничества, и, по данным UNCLOS, эта территория также принадлежит тиморскому народу. ${ }^{[35]}$

Нефть - это богатство, которое в Тиморе-Лешти в изобилии. Опосредованное линии должно быть прослежено для определения морского пространства между

Disponível em: https://www.nucleodoconhecimento.com.br/закон/международно-публичное- 
двумя странами, которые разделяют менее 400 морских миль. Запасы природного газа и нефти были обнаружены австралийскими компаниями в Тиморе-Лешти до обретения ими независимости. По этой причине австралийцы оказали большое сопротивление окончательному договору о праве на эксплуатацию Тиморского моря. Трудности, с которыми сталкиваются эти люди в получении своих морских прав, являются важными вопросами. Анализ деталей, предшествовавших окончательному договору, осуществленному в 2018 году, который касается тиморских границ, имеет важное значение для понимания доли событий, которые означает этот пакт. [36]

\section{4. ДОГОВОР МЕЖДУ АВСТРАЛИЕЙ И ТИМОРОМ-ЛЕШТЕ}

В 2002 году Тимор-Лешти получил независимость от Индонезии, но с этого года окончательные морские границы Тимора не были демаркированы. Австралийцы на протяжении многих лет не заинтересованы в решении морских границ, соблюдающих нормы международного права. Они намеревались остаться, используя ресурсы моря, которые им не принадлежали. Хотя они нанесли ущерб развитию Тимора-Лешти в ряде районов в течение длительного времени, в пакте не предусмотрена компенсация ущерба, причиненного с 2002 года. ${ }^{[37]}$

Тиморскому народу не будет возмещаться ущерб, причиненный его эволюции в таких областях, как образование, социальное, экономическое, политическое, в частности, требующих минимальных фринансовых ресурсов. Однако когда этот пакт был осуществлен, было отмечено, что На протяжении многих лет Австралия сильно пострадала от этого пакта. ${ }^{[38]}$ В целях поощрения развития, промышленного, технологического и экономического развития тиморцев, было решено, что компания, которая будет проводить разведку Большого Восхода, должна будет нанимать граждан Тимора-Лешти, облегчая им подготовку поощрение развития их исследований, а также будет обязанпринять принять страну в качестве первого варианта приобретения товаров и услуг. ${ }^{[39]}$

Disponível em: https://www.nucleodoconhecimento.com.br/закон/международно-публичное- 
Во избежание экономических потерь Австралия вышла из ряда международных договоров, которые она являлась неотъемлемой частью за несколько месяцев до обретения Тимором-Лешти независимости. ${ }^{[40]}$ Для того чтобы ни одна из стран не соблюдала пакт в будущем, государства оговаривали, что договор не будет подпадать под одностороннее право на денонсацию, вывод или приостановление. В тексте документа было разъяснено, что все положения, изложенные в договоре и приложениях, являются частью пакта и не могут быть проигнорированы или выделены. Перед лицом возможного будущего спора была достигнута договоренность о том, что он может быть урегулирован с помощью членов согласительной комиссии, которые выступили посредником в пакте между двумя странами в 2018 году. Однако при постоянстве разногласий по этим вопросам вопросы, рассматриваемые при вмешательстве членов Согласительного комитета, могут быть переданы в арбитражный суд, и это второе решение будет иметь обязательную силу. ${ }^{[41]}$

6 марта 2018 года было заключено соглашение между Тимором-Лешти и Австралией. Этот пакт разгранишает континентальный бассейн. В этом документе, согласно ст. ст. 1-й договор о морской границе Тимор-Леште. ${ }^{[42] ~ В ~}$ этом новом контексте Тимору-Лешти становится разрешено осуществлять эксплуатацию морских почвенных ресурсов, таких, как нефть и природный газ, в дополнение к предоставлению выгод правам из исключительной экономической зоны. Эта страна также получила право эксплуатировать другие морские ресурсы, такие, как рыболовство, что позволило увеличить финансовые ресурсы для страны. [43] 
Рисунок 4 - Договор Австралии и Тимора-Лешти на границах Тимора

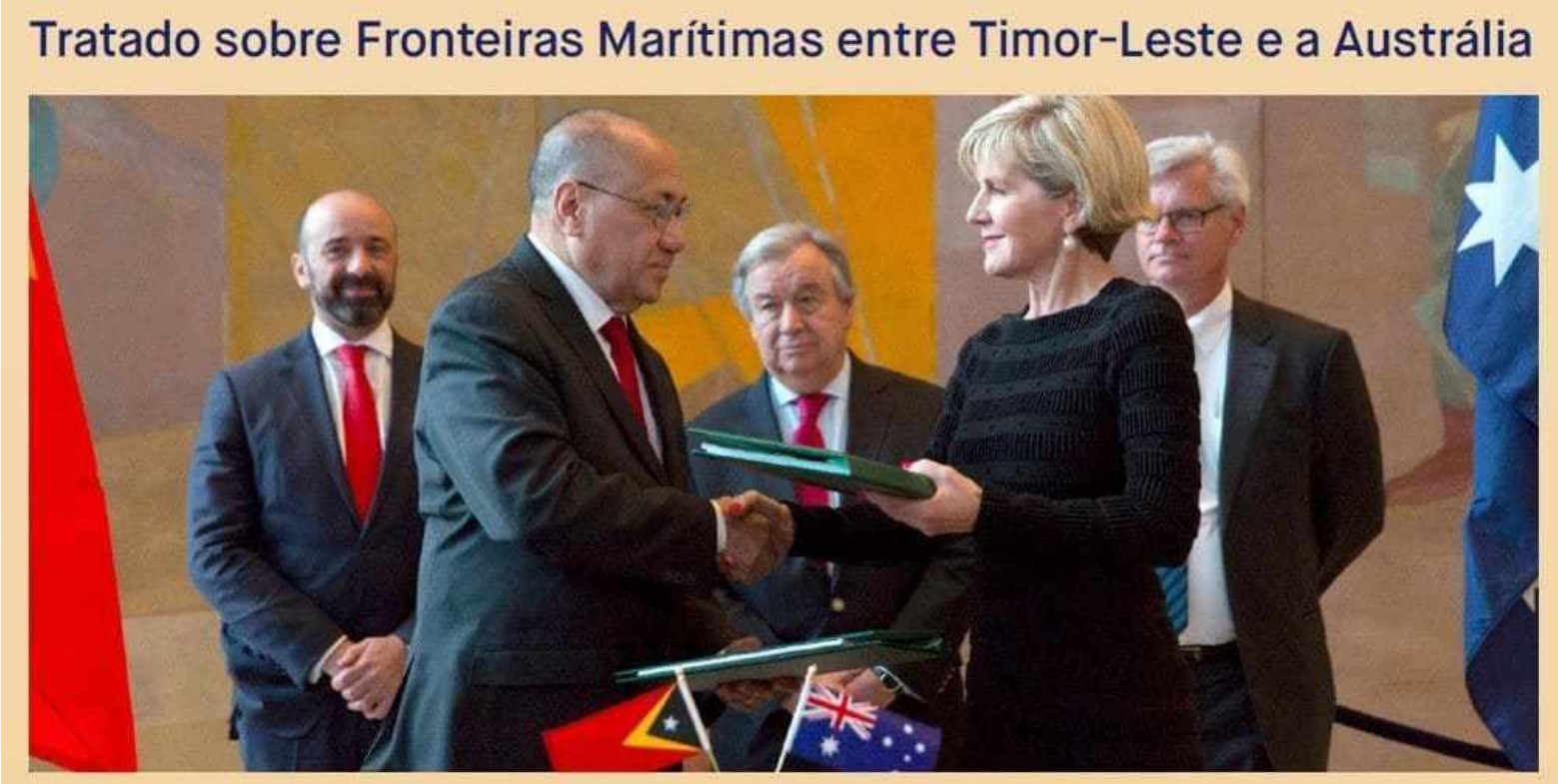

Источник: Тимор-Лешти (АВСТРАЛИЯ, 2018[44]

Тимор-Лешти и Австралия смягчили свои интересы для урегулирования разногласий, которые не позволили им договориться. В морской территориальной зоне, где расположен Большой Восход, было решено, что она будет принадлежать каждой из стран, участвующих в соглашении, в двое лет от результатов операции этого морского территориального района. Лагеря БайуУндан, Буфффало и Китан полностью интегрировали тиморскую территорию. ${ }^{[45]}$

Пути совместного использования доходов между Тимором-Лешти и Австралией не определены, поскольку они будут зависеть от нескольких фракторов. Чем больше способность разрабатывать методы и применять их, тем выше будет их прибыль. В соответствии с способами изучения поля Большого Восхода, результаты будут общими. В год, в котором был заключен пакт, было решено, что доходы от нефтяных месторождений будут принадлежать Австралии и 70\% в Тиморе-Лешти в случае увеличения геологоразведочных работ путем разработки газопровода для тиморского народа. Было также предсказано, что в случае, если месторождения Большого восхода солнца будут разработаны через

Disponível em: https://www.nucleodoconhecimento.com.br/закон/международно-публичное- 
трубопровод в Австралию, проценты будут изменены, что составит 20\% для австралийцев и $80 \%$ для тиморцев. ${ }^{[46]}$

В окончательном договоре о границах, в соответствии с искусством. 12 из правового документа было определено, что разведка газа и нефти в районе месторождения Большой Восход будет зависеть от определения между сторонами плана развития. Получается, что после начала геологоразведочных работ в морском регионе, которые бы разделили доходы, контрактная компания подчинится исключительной юрисдикции страны, где она находится. Будет создан Наблюдательный совет в составе двух представителей тимора-лешти и представителя Австралии. Для поиска решений судебных разбирательств будет создать Независимый комитет по урегулированию конфликтов для принятия решений по стратегиям, принятым для разведки нефтяного месторождения, о котором говорилось выше. ${ }^{[47]}$

На протяжении десятилетий Австралия демонстрировала свое намерение получать прибыль от эксплуатации нефтяных месторождений в полном объеме. Необходимо международное вмешательство для уменьшения конфликта из-за границ между тиморцами и австралийцами. Окончательный Договор о границах касается средней линии и боковых ограничений на территории Тимора-Лешти и делится доходами от нефтяного региона между вовлеченными странами. Но этот пакт не исключает возможности будущих конфликтов из-за прибыли от месторождений Большого Восхода. Многие вопросы находятся на рассмотрении, требуя возникновения конкретных конфликтов для принятия позиций. Столкнувшись с этой новой ситуацией, тиморский народ столкнется с рядом препятствий, с тем чтобы он мог пользоваться всеми возможностями для своего развития в различных областях. ${ }^{[48]}$

\section{MEHTEC K TIMOR-LESTE DEVELOPMENT}

Тимор-Лешти является морским государством, а не только нефтью. Есть несколько секторов, которые могут способствовать эволюции нации. На 


\section{MULTIDISCIPLINARY SCIENTIFIC JOURNAL

протяжении многих лет он был исследован Португалией, Индонезией и Австралией. Немногие ресурсы были инвестированы в образование и инфраструктуру. В связи с пренебрежением Индонезии стране был причинен ущерб в развитии нескольких районов. Специалистов, имеющих технические, политические, юридические и административные навыки, немного, поскольку в период господства народа для выполнения деятельности в этих областях были наняты только иностранные специалисты. ${ }^{[49]}$

Рисунок 5 - Учащиеся школы на тиморской периферии

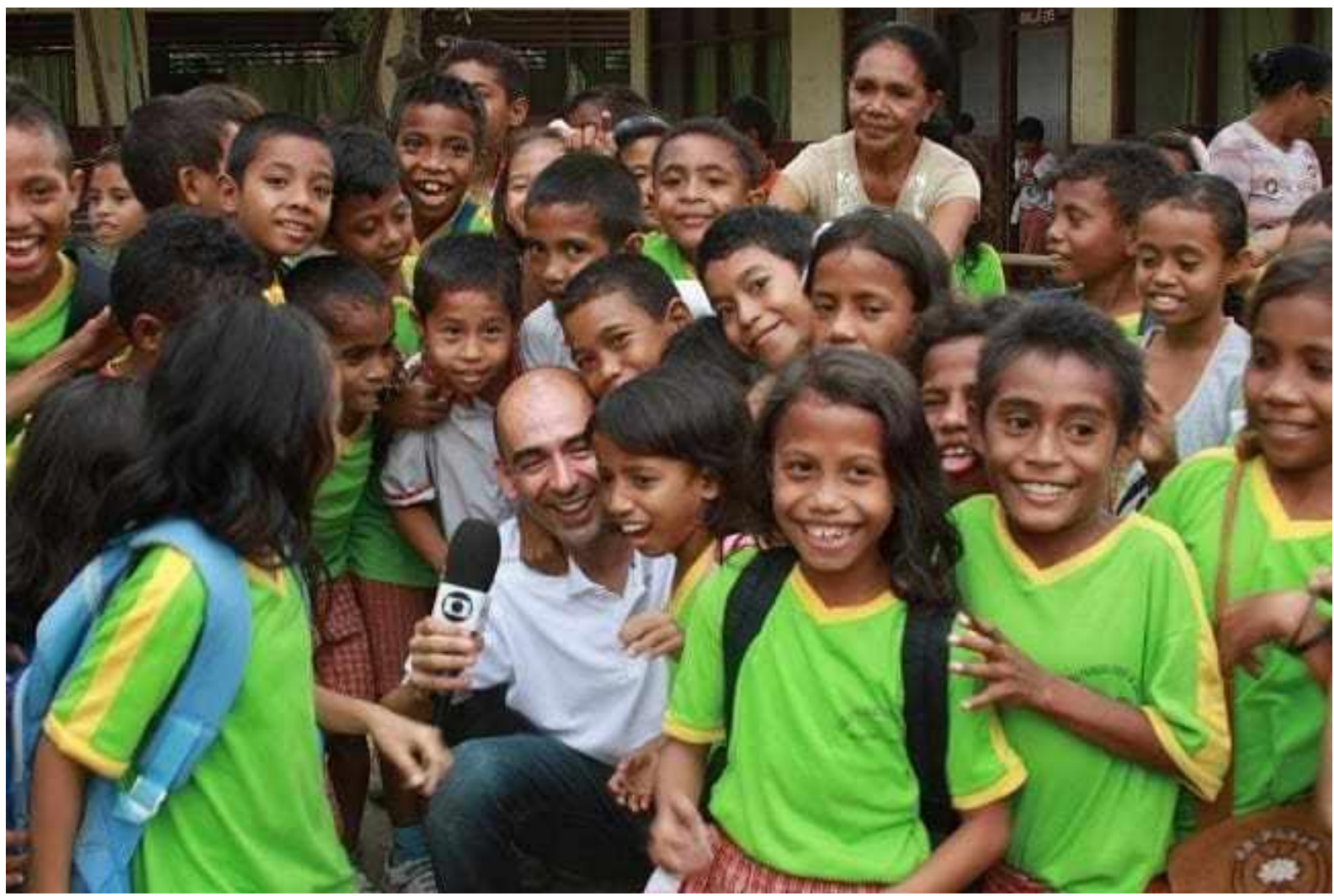

Источник: Партнеры мира (2011). C [50]

2011 года в Тиморе-Лешти действует стратегический план развития, который включает в себя развитие человеческого капитала, инфраструктуры, экономики, политики и административной сферы. Цель тиморского правительства заключается в достижении целей, изложенных в плане развития, к 2030 году. Ресурсы, выражаемые правами на эксплуатацию ее морской территории,

Disponível em: https://www.nucleodoconhecimento.com.br/закон/международно-публичное- 
приведут к более быстрому осуществлению целей, предложенных в тиморском плане развития. Пакт Австралии об окончательных границах, безусловно, породил бы несколько специфрических и беспрецедентных ситуаций. Конкретные знания о методах разведки нефти и природного газа будут необходимы для понимания того, какие альтернативы принесут стране наибольшую прибыль. После ратификации договора было установлено множество стандартов, с тем чтобы тиморцы могли пользоваться своими правами, но им потребуются квалифицированные специалисты в различных областях. И одной из основных проблем, с которыми сталкивается Тимор-Лешти, является нехватка опыта в области государственного управления с большими объемами фринансовых поступлений, которые будут увеличиваться в связи с окончательным договором о его границах. ${ }^{[51]}$

В договорном документе были установлены стандарты с участием крупных международных компаний-исследователей. Нефтяные компании должны вносить свой вклад в развитие тимор-леште, предпочтительно нанимая специалистов, услуги и продукты в стране. Тиморцы будут иметь отношение не только к представителям австралийского правительства, но и к опытным частным инициативам. Иностранные представители австралийского правительства или частные компании из различных стран, возможно, обладают огромными возможностями для переговоров и борьбы с неопытными тиморцами. В Тиморе-Лешти есть профессионалы с небольшимтехническими техническими навыками, но такая ситуация не должна ставить под угрозу развитие. Миссия этих предпринимателей будет заключаться в оказании помощи в обучении и обучении навыкам и знаниям, необходимым работникам для выполнения задач, связанных с разведочной деятельностью. Увеличение объема финансовых ресурсов будет способствовать трансформации секторов, технических, административных, политических, правовых, среди прочего, способствуя возникновению препятствий на пути развития страны. ${ }^{[52]}$

Разведка газа и нефти потребует от законодательной власти Тимора-Лешти информации о появлении новых фактов, вытекающих из этой 
деятельности. Государственные учреждения должны будут быстро найти ответ на расхождения между государством, представителями компанийэксплуататоров и Австралии. Хотя компания, заключиващая контракт, обязана подчиняться исключительной юрисдикции страны, в которой она находится, следует рассмотреть опыт и способность представителей частного сектора манипулировать переговорами. Неоспоримо, что правительство Тимора-Лешти занимает должности, способствующие прогрессу в различных районах страны, однако фрактом является то, что тиморские исполнительные, законодательные и судебные органы все еще развиваются, поскольку это очень молодая страна. ${ }^{[53]}$

Тимор-Лешти имеет большой опыт боевых действий, поскольку народ организовался против вторжения в Индонезию и получил свою независимость. ${ }^{[54]}$ В настоящее время она продвигается в поисках образования, инфраструктуры, экономики, политики и адекватного административного управления гражданами. В пакте об окончательных границах было признано неустойчивость ТимораЛешти. И механизмы, которые помогут в развитии страны, были позитивными в соглашении. ${ }^{[55]}$

Перед правительством Тимора-Лешти будут стоят сложные задачи, и потребуется правовой и административный сектор, готовый к новым действиям. В течение переходного периода разведки этого региона необходимо будет издать доклады и планы разработки месторождений Баю-Ундан, Буффрало и Китана. Эта обязанность потребует специальных технических знаний о разведке нефти и газа. ${ }^{[56]}$ Многие секторы связаны с развитием нации. Правительство Тимора-Лешти должно проводить инвестиционную политику в секторах, в которых имеются возобновляемые источники эксплуатации. Следует рассмотреть положения Пакта о тиморских границах, касающиеся обязанности компаний оказывать содействие в развитии различных секторов. Государство должно будет стремиться к развитию в той же мере, в какой оно должно требовать частной инициативы, чтобы внести свой вклад в развитие страны..57] 
Экономический рост имеет решающее значение для прогресса в области инфраструктуры, политики и управления. Экономический рост ВИМОР-Лешти связан с сельским хозяйством, туризмом и морским сектором, а не только с разведкой нефти и газа. Сельское хозяйство имеет важное значение для Тимора-Лешти, а также имеет большое значение для ряда других стран. Из него то, что пища производится. Первичная продукция из сельского хозяйства может использоваться в промышленности, торговле и секторе услуг. Они могут стать основой для поддержания национальной и международной экономики. ${ }^{[58]}$

Изучение морской экономики также имеет решающее значение для развития тиморской нации. Многие люди зависят от моря и поддерживают себя ресурсами, получаемыми в результате рыболовства и сбора морских видов. Получается, что на морской территории этой страны происходит естественный проход рыбы. И благодаря событиям, вызванным окончательным пактом о границах, несколько видов рыб могут быть использованы национальными отраслями промышленности. В дополнение к увеличению доходов для появления отраслей, заинтересованных во многих видов школ, что этот регион, эта страна находится в Коралловый треугольник. Это культурное наследие, которое может быть оценено туризмом, а также может служить интересом для научных исследований. Вышеуказанные характеристики могут привести к прямому и косвенному увеличению ресурсов государства при условии принятия надлежащих административных мер. ${ }^{[59]}$

Инфраструктура тиморских портов и аэропортов также имеет основополагающее значение для роста страны. Параметры стратегических сооружений должны контролировать потребности судоходства по глобальному сценарию, через который тиморская территория может осуществляться транзитом через тиморской территории. Порты Дили, О-кус, Гера, Каравела и Ком в настоящее время имеют неадекватные характеристики, требующие инвестиций, которые должны рассматриваться в качестве промышленных центров. Эта эволюция создаст возможности для Тимора-Лешти стать транзитом нефтяных танкеров, а 
также сделает его страной, обладающей крупным промышленным центром, соединяющим Тихий и Индийский океаны. ${ }^{[60]}$

Тимору-Лешти необходимо продолжать продвижение вперед во многих областях. Сельскохозяйственный, нефтяной, морской, туристический, образовательный, юридический, политический и экономический секторы нуждаются в преобразованиях. Уже существует план политики в области развития, который был разработан в 2011 году. Однако необходимо адаптировать его к новой реальности, в которой находится страна, после изменений, которые произошли в определении ее окончательных морских границ.61] Конкретные стратегии для каждого сектора необходимо будет развернуть на национальном уровне. И, исходя из этих новых целей, должны быть приняты позиции с нефтегазовыми разведочными компаниями, как и все решения государства для достижения этих целей роста. ${ }^{62]}$

\section{6. ЗАКЛЮЧЕНИЕ}

Тимор-Лешти расположен в юго-восточной Азии и является очень молодой страной, которая получила независимость в 2002 году. Это сосед Индонезии, который лежит на севере, а на юге Австралия. Она имеет нацию, характеризующуюся своей силой и борьбой. Этот воин и страдающие люди общаются через португальский язык и Tetum, официально, но на территории есть более 14 родных языков. Он был колонизирован Португалией и захвачен Индонезией в 1975 году. Он располагает сокровищем, расположенным на его морской территории из-за нефти и природного газа, которые встречаются в Тиморском море. Эти богатства Тимора-Лешти были предметом битвы с Австралией. Разногласия между австралийцами и тиморцами начались за несколько месяцев до обретения Независимости Тимором-Лешти Индонезией. Австралия не заинтересована в проведении переговоров, как это предусмотрено международным морским правом, с тем чтобы избежать потери поступлений от Тиморского моря. Но в 2018 году с австралийцами был подписан Окончательный договор о границах Тимора-Лешти. Это был исторический 
момент, когда народ получил признание права пользоваться своим территориальным морем.

Деликатное экономическое положение страны было признано в окончательном Договоре о границе между Тимором-Лешти. Нехватка экономических ресурсов связана с разрушительной эксплуатацией этой страны. Португалия инвестировала мало в течение более 400 лет, в которых эта страна была своей колонией. После освобождения от португальского господства произошло новое нападение на Тимор-Лешти. На протяжении более двадцати четырех лет тиморцы страдали от оккупации Индонезии, однако были сделаны небольшие инвестиции. Однако с того периода, когда тиморский народ проявлял интерес к борьбе за свою независимость, все было разрушено индонезийским народом. На начальном этапе оккупации Тимора-Лешти Индонезией международное сообщество внесло свой вклад в восстановление страны в рамках основного этапа.

Независимость тиморцев не дает им немедленного права завладеть принадлежащими им морскими богатствами в силу того, что они находятся на их территории. Временные соглашения о границах, пакты, которые нанесли ущерб тиморцам, были заключены с Австралией до 2018 года. С 2002 года ТиморЛешти претендует на право собственности на свою морскую территорию, как это предусмотрено нормами международного права, UNCLOS/1982. Оказывается, что за несколько месяцев до обретения Тимором-Лешти независимости Австралия вышла из ряда международных пактов.

Поскольку морские территории Тимора-Лешти и Австралии разделены расстоянием менее 400 морских миль, на небольшом расстоянии между территориями двух стран, принятая линия разграничения границы была определена стандартом равной и средней линии. Это модель, предусмотренная в Конвенции Организации Объединенных Наций о правах моря 1982 года, используемой для урегулирования конфлликтов, которые были над территориями, которые отдаляются менее чем на 400 морских миль.

Disponível em: https://www.nucleodoconhecimento.com.br/закон/международно-публичное- 
Австралийцы на протяжении многих лет избегали достижения соглашения с тиморцами об окончательных границах в соответствии с нормами Конвенции Организации Объединенных Наций о правах моря. Цель этой позиции состояла в том, чтобы не уважительно относиться к способу делимитации морских границ, который предусматривает в качестве стандарта принятие средней линии и равновесность в конкретных конфликтах по сравнению с определением границ. Причина исключения Австралии из международного сообщества связана с расширением прибыли от эксплуатации моря, которое принадлежит тиморскому народу.

После нескольких попыток окончательно договориться о тиморских границах с Австралией страна добилась успеха. Ясно и конкретно в документе, который содержит более 11 статей, постоянные двусторонние морские границы рассматривались по существу равной линии между двумя странами. В ТимореЛешти границы делимитированы, как это предусмотрено конвенцией Организации Объединенных Наций по морскому праву. В договоре было решено, что существует неделимая связь между морской границей Тимора-Лешти и Австралией. Было признано существование морского района, принадлежащего двум государствам, участвующим в пакте.

В ходе подготовки документа стороны поделились доходами от эксплуатации больших восходовых полей и положительно в тексте международного пакта необходимость разработки правил, касающихся эксплуатации полей региона, принадлежащих двум Стран. Установлено, что нормы, согласованные в Договоре или в его приложениях, не могут быть частично несоблюдаться ни одной из заинтересованных сторон. Было также регламентировано, что планы разведки морских богатств должны быть разработаны до начала процедур, а также было также решено, что нефтяные компании должны будут закупать продукты и услуги предпочтительно от тиморского народа.

Окончательный пограничный пакт Тимора-Лешти является не только общим соглашением между правительствами двух стран. Этот тиморский и 
австралийский пакт также охватывает обязательства в области частной инициативы. Обязанности были выделены компаниям, которые будут вести разведку нефти и газа в районе месторождений Большого Восхода. Они должны способствовать развитию Тимора-Лешти.

Необходимо устранить многие препятствия, с тем чтобы Тимор-Лешти мог широко развиваться, несмотря на то, что он заслужил право исследовать свою морскую территорию. Нефть и газ являются невозобновляемыми ресурсами, то есть являются источниками дохода с оценочным прекращением. Но они являются источниками немедленного и прибыльного дохода. Развитие образования, инфраструктуры, сельского хозяйства, туризма и предоставления услуг имеет важное значение для создания прочной и возобновляемой среднесрочной и долгосрочной базы доходов. Страна сталкивается с рядом препятствий, таких как небольшая инфраструктура и низкий уровень образования, но с 2002 года значительно растет.

В капиталистическом мире неоспоримо, что фринансовые ресурсы являются определяющими фракторами для широкой эволюции страны. Увеличение поступлений от разведки нефти и газа приведет к увеличению фринансовых поступлений, что будет способствовать развитию образования и инвестициям в инфраструктуру портов и аэропортов Тимора-Лешти. Если до заключения Договора об окончательных границах образование, инфраструктура, сельское хозяйство и промышленное рыболовство были препятствием на пути развития тиморцев, то ожидается, что после заключения окончательного пакта с Австралией эта реальность будет изменена.

\section{ссылки}

BRASIL. Decreto no 99.165, de 12 de março de 1990. Convenção das Nações Unidas sobre o Direito do Mar. Brasília: Planalto, 1990. Disponível em: https://www2.camara.leg.br/legin/fed/decret/1990/decreto-99165-12-marco-1990328535-publicacaooriginal-1-pe.html. Acesso em 15 abr.19. 
DEL'OMO, Florisbal de Souza. Curso de direito internacional público. Rio de Janeiro: Forense, 2006.

GIBERTONI, Carla Adriana Comitre. Teoria e prática do direito marítimo. Rio de Janeiro: Renovar, 1998.

GOMES, Danaciano. Timor Leste: A economia do mar: um contributo para desenvolvimento sustentável. Aveiro: Mare Liberum, 2016.

GUSMÃO, Kay Raia Xanana. Breve história do mar do Timor. In: GOVERNO DO ESTADO DO TIMOR LESTE. Novas Fronteiras: conciliação histórica das fronteiras marítimas no mar do timor. Dili: Gabinete das Fronteiras marítimas, 2018.

MARCONI, Maria de Andrade, Lakatos, Eva, Maria. Fundamentos da metodologia cientifica. São Paulo: Atlas. 2003.

MARITIME BOUNDARY OFFICE. New frontiers: Timor-Leste's historic conciliation on maritime boundaries in the timor sea. [S. I.], 2015. Disponível em: http://www.gfm.tl/wp-content/uploads/2015/11/Website-map-of-Timor-Sea.pdf. Acesso em: 04 maio 2019.

MATTOS, Adherbal. Meira. O novo direito do mar. Rio de Janeiro: Renovar. 1996.

PEREIRA, Eliana Sofia da Silva. Contributo crítico para a compreensão do regime do Mar de Timor à luz do Direito Internacional. 2013. 87 f. Dissertação. (Mestrado em Ciências Jurídicas Internacionais) Faculdade de direito- Universidade Nova de Lisboa, 2013. $\quad$ p.14. Disponível em: https://run.unl.pt/bitstream/10362/17481/1/Pereira_2013.pdf. Acesso em: 01 abr. 2019.

REPÚBLICA DEMOCRÁTICA DE TIMOR-LESTE. Ministério das finanças. Orçamento geral do Estado 2018. Díli: Gabinete Ministerial, 2018. p. 7. Disponível em: https://www.mof.gov.tl/wp-content/uploads/2018/08/BB5_Port.pdf. Acesso em: 15 maio 2019. 
REPUBLICA DEMOCRÁTICA DO TIMOR LESTE. História do Timor Leste. Governo do Timor Leste, Dili, [s. d.]. Disponível em: http://timor-leste.gov.tl/?p=29\&lang=pt. acesso em: 05 maio 2019.

REZEK, José Francisco. Direito internacional público: curso elementar. 10. ed. rev. e atual. São Paulo: Saraiva, 2005.

RIBEIRO, Marilda, Rosado de Sá. Direito do petróleo. 3. ed. rev. atual. e ampl. Rio de Janeiro: Renovar, 2018.

TIMOR LESTE; AUSTRÁLIA. Tratado sobre fronteiras marítimas entre Timor Leste e Austrália que estabelece as respectivas fronteiras do mar do Timor Leste. Nova York: [s.n.], 2018. p. 1. Disponível em: http://www.gfm.tl/wpcontent/uploads/2018/03/Port-Timos-Sea-Maritime-BoundaryTreaty_Portuguese.pdf. Acesso em:04 maio 2018.

TIMOR SEA JUSTICE. All of the contested oil \& gas fields are on EastTimor's side of the median line ie closer to \#Timor than Australia. Dili, 01 mar. 2016. Tiwitte: @timor sea justice. Disponível em: https://twitter.com/TimorSeaJustice/status/704895304701763584. Acesso em: 25 maio. 2019.

ZANELLA, T. V. Curso de direito do mar. Curitiba: Juruá, 2013.

\section{APÊNDICE - REFERENCIAS DE NOTA DE RODAPÉ}

3. GOMES, Danaciano. Timor-Leste: A economia do mar: um contributo para desenvolvimento sustentável. Aveiro: Mare Liberum, 2016.

4. GUSMÃO, Kay Raia Xanana. Breve história do mar do Timor. In: GOVERNO DO ESTADO DO TIMOR LESTE. Novas Fronteiras: conciliação histórica das fronteiras marítimas no mar do timor. Dili: Gabinete das Fronteiras marítimas, 2018. p. 6. 
5. RIBEIRO, Marilda, Rosado de Sá. Direito do Petróleo. 3. ed. rev. atual. e ampl. Rio de Janeiro: Renovar, 2018.

6. RIBEIRO, Marilda, Rosado de Sá. Direito do Petróleo. 3. ed. rev. atual e ampl. Rio de Janeiro Renovar, 2018.

7. GOMES, Danaciano. Timor Leste: a economia do mar: um contributo para desenvolvimento sustentável. Aveiro: Mare Liberum, 2016.

8. MARCONI, Maria de Andrade, Lakatos, Eva, Maria. Fundamentos da metodologia cientifica. São Paulo: Atlas. 2003.

9. GUSMÃO, Kay Raia Xanana. Breve história do mar do Timor. In: GOVERNO DO ESTADO DO TIMOR LESTE. Novas Fronteiras: conciliação histórica das fronteiras marítimas no mar do timor. Dili: Gabinete das Fronteiras marítimas, 2018. p. 7-8.

10. MARITIME BOUNDARY OFFICE. New frontiers: Timor-Leste's historic conciliation on maritime boundaries in the timor sea. [S. I.], 2015. Disponível em: http://www.gfm.tl/wp-content/uploads/2015/11/Website-map-of-Timor-Sea.pdf. Acesso em: 04 maio 2019.

11. GOMES, Danaciano. Timor Leste: A economia do mar: um contributo para desenvolvimento sustentável. Aveiro: Mare Liberum, 2016. p. 35-36.

12. GOMES, Danaciano. Timor Leste: A economia do mar: um contributo para desenvolvimento sustentável. Aveiro: Mare Liberum, 2016. p. 37 e 38

13. PEREIRA, Eliana Sofia da Silva. Contributo crítico para a compreensão do regime do Mar de Timor à luz do Direito Internacional. 2013. 87 f. Dissertação. (Mestrado em Ciências Jurídicas Internacionais) Faculdade de direito- Universidade Nova de Lisboa, 2013. p.14. Disponível em: https://run.unl.pt/bitstream/10362/17481/1/Pereira_2013.pdf. Acesso em: 01 abr. 2019. 
14. PEREIRA, Eliana Sofia da Silva. Contributo crítico para a compreensão do regime do Mar de Timor à luz do Direito Internacional. 2013. 87 f. Dissertação. (Mestrado em Ciências Jurídicas Internacionais) Faculdade de direito- Universidade Nova de Lisboa, 2013. p.14. Disponível em: https://run.unl.pt/bitstream/10362/17481/1/Pereira_2013.pdf. Acesso em: 01 abr. 2019.

15. TIMOR LESTE; AUSTRÁLIA. Tratado sobre Fronteiras Marítimas entre Timor Leste e Austrália que estabelece as respectivas fronteiras do mar do Timor Leste. Nova York: [s.n.], 2018. p. 1. Disponível em: http://www.gfm.t//wpcontent/uploads/2018/03/Port-Timos-Sea-Maritime-Boundary-

Treaty_Portuguese.pdf. Acesso em:04 maio 2018.

16. PEREIRA, Eliana Sofia da Silva. Contributo crítico para a compreensão do regime do Mar de Timor à luz do Direito Internacional. 2013. 87 f. Dissertação. (Mestrado em Ciências Jurídicas Internacionais) Faculdade de direito- Universidade Nova de Lisboa, 2013. p.14. Disponível em: https://run.unl.pt/bitstream/10362/17481/1/Pereira_2013.pdf. Acesso em: 01 abr. 2019.

17. MATTOS, Adherbal. Meira. O novo Direito do Mar. Rio de Janeiro: Renovar. 1996. p. 04

18. RIBEIRO, Marilda, Rosado de Sá. Direito do Petróleo. 3. ed. rev. atual. e ampl. Rio de Janeiro: Renovar, 2018.

19. Zona Contígua é Faixa entre o mar territorial e o alto-mar, fixada entre 12 e 24 milhas, na qual o Estado exerce sua jurisdição sobre atividades marítimas e sobre diversos interesses nacionais.

20. Plataforma continental é definida como uma faixa de terra submersa, em toda a extensão do litoral do continente. Geralmente, a plataforma possui uma extensão de 70 a $90 \mathrm{~km}$, e profundidade de 200 metros, até atingir as bacias oceânicas. 
21. Nota explicativa: Águas adjacentes são aquelas que banham as margens do território de uma nação.

22. ZANELLA, T. V. Curso de Direito do Mar. Curitiba: Juruá, 2013.

23. ZANELLA, T. V. Curso de Direito do Mar. Curitiba: Juruá, 2013.

24. RIBEIRO, Marilda, Rosado de Sá. Direito do Petróleo. 3. ed. rev. atual. e ampl. Rio de Janeiro: Renovar, 2018.

25. REZEK, José Francisco. Direito Internacional Público: curso elementar. 10. ed. rev. e atual. São Paulo: Saraiva, 2005. p.307

26. BRASIL. Decreto no 99.165, de 12 de março de 1990. Convenção das Nações Unidas sobre o Direito do Mar. Brasília: Planalto, 1990. Disponível em: https://www2.camara.leg.br/legin/fed/decret/1990/decreto-99165-12-marco-1990328535-publicacaooriginal-1-pe.html. Acesso em 15 abr.19.

27. GIBERTONI, Carla Adriana Comitre. Teoria e prática do direito marítimo. Rio de Janeiro: Renovar, 1998. p.33.

28. GOMES, Danaciano. Timor Leste: A economia do mar: um contributo para desenvolvimento sustentável. Aveiro: Mare Liberum, 2016. p.51

29. PEREIRA, Eliana Sofia da Silva. Contributo crítico para a compreensão do regime do Mar de Timor à luz do Direito Internacional. 2013. 87 f. Dissertação. (Mestrado em Ciências Jurídicas Internacionais) Faculdade de direito- Universidade Nova de Lisboa, 2013. p.56. Disponível em: https://run.unl.pt/bitstream/10362/17481/1/Pereira_2013.pdf. Acesso em: $01 \mathrm{abr}$. 2019.

30. GOMES, Danaciano. Timor Leste: A economia do mar: um contributo para desenvolvimento sustentável. Aveiro: Mare Liberum, 2016. p.110 e 111 
31. RIBEIRO, Marilda, Rosado de Sá. Direito do Petróleo. 3. ed. rev. atual. e ampl. Rio de Janeiro: Renovar, 2018. P. 74 à 80

32. GUSMÃO, Kay Raia Xanana. Breve história do mar do Timor. In: GOVERNO DO ESTADO DO TIMOR LESTE. Novas Fronteiras: conciliação histórica das fronteiras marítimas no mar do timor. Dili: Gabinete das Fronteiras marítimas, 2018.

33. DEL'OMO, Florisbal de Souza. Curso de Direito Internacional Público. Rio de Janeiro: Forense, 2006. p. 292.

34. TIMOR SEA JUSTICE. All of the contested oil \& gas fields are on EastTimor's side of the median line ie closer to \#Timor than Australia. Dili, 01 mar. 2016. Tiwitte: @timor sea justice. Disponível em: https://twitter.com/TimorSeaJustice/status/704895304701763584. Acesso em: 25 maio. 2019.

35. GUSMÃO, Kay Raia Xanana. Breve história do mar do Timor. In: GOVERNO DO ESTADO DO TIMOR LESTE. Novas Fronteiras: conciliação histórica das fronteiras marítimas no mar do timor. Dili: Gabinete das Fronteiras marítimas, 2018. p. 34 e 35

36. DEL'OMO, Florisbal de Souza. Curso de Direito Internacional Público. Rio de Janeiro: Forense, 2006. p. 292

37. DEL'OMO, Florisbal de Souza. Curso de Direito Internacional Público. Rio de Janeiro: Forense, 2006. p. 292

38. REPUBLICA DEMOCRÁTICA DO TIMOR LESTE. História do Timor Leste.

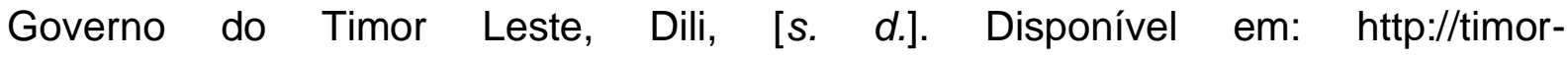
leste.gov.tl/?p=29\&lang=pt. acesso em: 05 maio 2019.

39. TIMOR LESTE; AUSTRÁLIA. Tratado sobre Fronteiras Marítimas entre Timor Leste e Austrália que estabelece as respectivas fronteiras do mar do Timor Leste. Nova York: [s.n.], 2018. p. 1. Disponível em: http://www.gfm.tl/wp- 
content/uploads/2018/03/Port-Timos-Sea-Maritime-Boundary-

Treaty_Portuguese.pdf. Acesso em:05 maio 2018.

40. PEREIRA, Eliana Sofia da Silva. Contributo crítico para a compreensão do regime do Mar de Timor à luz do Direito Internacional. 2013. 87 f. Dissertação. (Mestrado em Ciências Jurídicas Internacionais) Faculdade de direito- Universidade Nova de Lisboa, 2013. p.14-15. Disponível em: https://run.unl.pt/bitstream/10362/17481/1/Pereira_2013.pdf. Acesso em: 01 abr. 2019

41. TIMOR LESTE; AUSTRÁLIA. Tratado sobre Fronteiras Marítimas entre Timor Leste e Austrália que estabelece as respectivas fronteiras do mar do Timor Leste. Nova York: [s.n.], 2018. p. 1. Disponível em: http://www.gfm.t//wpcontent/uploads/2018/03/Port-Timos-Sea-Maritime-Boundary-

Treaty_Portuguese.pdf. Acesso em:05 maio 2018.

42. TIMOR LESTE; AUSTRÁLIA. Tratado sobre Fronteiras Marítimas entre Timor Leste e Austrália que estabelece as respectivas fronteiras do mar do Timor Leste. Nova York: [s.n.], 2018. p. 1. Disponível em: http://www.gfm.t//wpcontent/uploads/2018/03/Port-Timos-Sea-Maritime-Boundary-

Treaty_Portuguese.pdf. Acesso em:05 maio 2018.

43. GIBERTONI, Carla Adriana Comitre. Teoria e prática do direito marítimo. Rio de Janeiro: Renovar, 1998. p. 33.

44. TIMOR LESTE; AUSTRÁLIA. Tratado sobre Fronteiras Marítimas entre Timor Leste e Austrália que estabelece as respectivas fronteiras do mar do Timor Leste. Nova York: [s.n.], 2018. p. 1. Disponível em: http://www.gfm.tl/wpcontent/uploads/2018/03/Port-Timos-Sea-Maritime-Boundary-

Treaty_Portuguese.pdf. Acesso em:05 maio 2018.

45. TIMOR LESTE; AUSTRÁLIA. Tratado sobre Fronteiras Marítimas entre Timor Leste e Austrália que estabelece as respectivas fronteiras do mar do Timor Leste. Nova York: [s.n.], 2018. p. 1. Disponível em: http://www.gfm.tl/wp- 
content/uploads/2018/03/Port-Timos-Sea-Maritime-Boundary-

Treaty_Portuguese.pdf. Acesso em:05 maio 2018.

46. TIMOR LESTE; AUSTRÁLIA. Tratado sobre Fronteiras Marítimas entre Timor Leste e Austrália que estabelece as respectivas fronteiras do mar do Timor Leste. Nova York: [s.n.], 2018. p. 1. Disponível em: http://www.gfm.tl/wpcontent/uploads/2018/03/Port-Timos-Sea-Maritime-BoundaryTreaty_Portuguese.pdf. Acesso em:05 maio 2018.

47. TIMOR LESTE; AUSTRÁLIA. Tratado sobre Fronteiras Marítimas entre Timor Leste e Austrália que estabelece as respectivas fronteiras do mar do Timor Leste. Nova York: [s.n.], 2018. p. 1. Disponível em: http://www.gfm.tl/wpcontent/uploads/2018/03/Port-Timos-Sea-Maritime-Boundary-

Treaty_Portuguese.pdf. Acesso em:05 maio 2018.

48. GOMES, Danaciano. Timor Leste: A economia do mar: um contributo para desenvolvimento sustentável. Aveiro: Mare Liberum, 2016. p. 59.

49. REPUBLICA DEMOCRÁtICA DO TIMOR LESTE. História do Timor Leste.

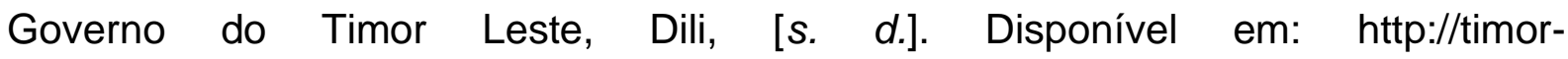
leste.gov.tl/?p=29\&lang=pt. Acesso em: 05 maio 2019.

50. O PRIMEIRO dia no Timor Leste. In: PARCEIROS pela paz. Dili, 06 jul. 2011. Disponível em: https://parceirospelapaz.wordpress.com/category/timor-leste/. Acesso em: 25 maio 2019.

51. REPÚBLICA DEMOCRÁTICA DE TIMOR-LESTE. Ministério das finanças. Orçamento geral do Estado 2018. Díli: Gabinete Ministerial, 2018. p. 7. Disponível em: https://www.mof.gov.tl/wp-content/uploads/2018/08/BB5_Port.pdf. Acesso em: 15 maio 2019.

52. TIMOR LESTE; AUSTRÁLIA. Tratado sobre Fronteiras Marítimas entre Timor Leste e Austrália que estabelece as respectivas fronteiras do mar do Timor 
Leste. Nova York: [s.n.], 2018. p. 1. Disponível em: http://www.gfm.tl/wpcontent/uploads/2018/03/Port-Timos-Sea-Maritime-BoundaryTreaty_Portuguese.pdf. Acesso em: 19 maio 2018.

53. GOMES, Danaciano. Timor Leste: A economia do mar: um contributo para desenvolvimento sustentável. Aveiro: Mare Liberum, 2016.

54. REPUBLICA DEMOCRÁtICA DO TIMOR LESTE. História do Timor Leste.

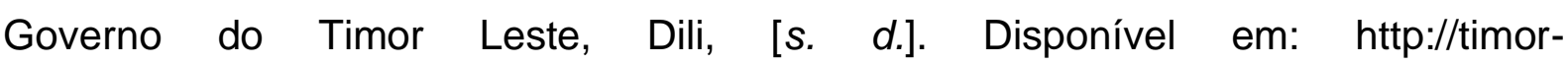
leste.gov.t//?p=29\&lang=pt. acesso em: 05 maio 2019

55. TIMOR LESTE; AUSTRÁLIA. Tratado sobre Fronteiras Marítimas entre Timor Leste e Austrália que estabelece as respectivas fronteiras do mar do Timor Leste. Nova York: [s.n.], 2018. p. 1. Disponível em: http://www.gfm.tl/wpcontent/uploads/2018/03/Port-Timos-Sea-Maritime-BoundaryTreaty_Portuguese.pdf. Acesso em: 19 maio 2018.Acessado: 05/05/19

56. TIMOR LESTE; AUSTRÁLIA. Tratado sobre Fronteiras Marítimas entre Timor Leste e Austrália que estabelece as respectivas fronteiras do mar do Timor Leste. Nova York: [s.n.], 2018. p. 1. Disponível em: http://www.gfm.tl/wpcontent/uploads/2018/03/Port-Timos-Sea-Maritime-BoundaryTreaty_Portuguese.pdf. Acesso em:05 maio 2018.

57. TIMOR LESTE; AUSTRÁLIA. Tratado sobre Fronteiras Marítimas entre Timor Leste e Austrália que estabelece as respectivas fronteiras do mar do Timor Leste. Nova York: [s.n.], 2018. p. 1. Disponível em: http://www.gfm.tl/wpcontent/uploads/2018/03/Port-Timos-Sea-Maritime-Boundary-

Treaty_Portuguese.pdf. Acesso em:05 maio 2018.

58. GOMES, Danaciano. Timor Leste: A economia do mar: um contributo para desenvolvimento sustentável. Aveiro: Mare Liberum, 2016 
59. GOMES, Danaciano. Timor Leste: A economia do mar: um contributo para desenvolvimento sustentável. Aveiro: Mare Liberum, 2016. p.114-115.

60. GOMES, Danaciano. Timor Leste: A economia do mar: um contributo para desenvolvimento sustentável. Aveiro: Mare Liberum, 2016.

61. REPÚBLICA DEMOCRÁTICA DE TIMOR-LESTE. Ministério das finanças. Orçamento geral do Estado 2018. Díli: Gabinete Ministerial, 2018. Disponível em: https://www.mof.gov.tl/wp-content/uploads/2018/08/BB5_Port.pdf. Acesso em: 15 maio 2019.

62. GOMES, Danaciano. Timor Leste: A economia do mar: um contributo para desenvolvimento sustentável. Aveiro: Mare Liberum, 2016.

Представлено: август 2019 года.

Утверждено: декабрь 2019 года. 